\title{
Late glacial and Holocene Ostracoda from the Melilla cold-water coral mound field
}

\author{
Claudius M. Pirkenseer ${ }^{1} \cdot$ Silvia Spezzaferri $^{1} \cdot$ Claudio Stalder $^{2}$
}

\begin{abstract}
The ostracod assemblages from sediment core TTR17-401G recovered from the Melilla cold-water coral mound field in the eastern Alboran Sea spanning the last $13 \mathrm{ka}$ are analysed quantitatively, taxonomically and palaeoecologically. The core can be subdivided in three distinct assemblages linked to environmental shifts during the Younger Dryas and the BøllingAllerød interstadial. A total of 9 ostracod species is recorded, Paracypris polita is dominant throughout the core. Common accessory taxa Cytherella robusta, Echinocythereis vidua and Macromckenziea ligustica characterize the well-oxygenated ostracod assemblage 2 affected by the Younger Dryas. Favourable growth conditions for ostracods during the latter are indicated by large-sized Krithe praetexta specimens.
\end{abstract}

Keywords Palaeoecology $\cdot$ Assemblage development $\cdot$ Hypoxia $\cdot$ Paracypris polita $\cdot$ Krithe praetexta $\cdot$ Systematic palaeontology

\section{Introduction}

The Alboran Sea as the westernmost part of the Mediterranean Sea is delimited by the lines Cape Trafalgar-Cape Spartel in the west and Cape de Gata-Cape Fegalo in the east that represents an approximately $400 \mathrm{~km}$ long and $200 \mathrm{~km}$ wide basin with water depths reaching about $1500 \mathrm{~m}$ (Fig. 1) (GEBCO https://www.gebco.net/data_ and_products/gridded_bathymetry_data/; IHO 1953). The Alboran Sea consists of several subbasins with the prominent Alboran Ridge separating the West Alboran Basin from the South Alboran Basins (Comas et al. 1999). The Melilla CWC mound field (MMF) is located southeast of the Cape Tres Forcas on a platform bordering the South Alboran Basin to the south.

Electronic supplementary material .

Claudius M. Pirkenseer

claudiusmarius.pirkenseer@unifr.ch

1 Section Geology and Palaeontology, University of Fribourg, Chemin du Musée 6, 1700 Fribourg, Switzerland

2 Federal Office of Public Health FOPH, Schwarzenburgstrasse 157, 3003 Bern, Switzerland
The submarine morphology of the MMF is characterized by up to $100 \mathrm{~m}$ high biogenic carbonate buildups with a diameter ranging up to $476 \mathrm{~m}$ that cover a surface of about $100 \mathrm{~km}^{2}$ in water depths ranging from 250 to $600 \mathrm{~m}$ (e.g. Fink et al. 2013).

Hydrologic exchange of three predominant water masses between the Atlantic Ocean and the Mediterranean Sea characterize the modern Alboran Sea. Modified Atlantic Water enters the Strait of Gibraltar in the uppermost water column as so-called Atlantic Jet (Fig. 1; Prieur and Sournia 1994; Viúdez et al. 1998; Renault et al. 2012), driving two main anticyclonic gyres of approximately $100 \mathrm{~km}$ diameter situated over the western and eastern Alboran Basins, respectively. Both main gyres are stable during summer, whereas in autumn and winter the flow regime especially of the Eastern Anticyclonic Gyre (EAG) fluctuates with seasonal hydrologic changes (Prieur and Sournia 1994; Vargas-Yáñez et al. 2002; Renault et al. 2012). The outflow of the Mediterranean Sea consists of the Levantine Intermediate Water close to the Iberian margin at around 200-600 m water depth and the Mediterranean Deep Water merging at the chokepoint of the Gibraltar Sill (Millot 1987). The shallow position of the MMF just east of the Cabo de Tres Forcas puts it under influence of the (modern) surface circulation of the intermittent and shifting EAG (Fink et al. 2013). 


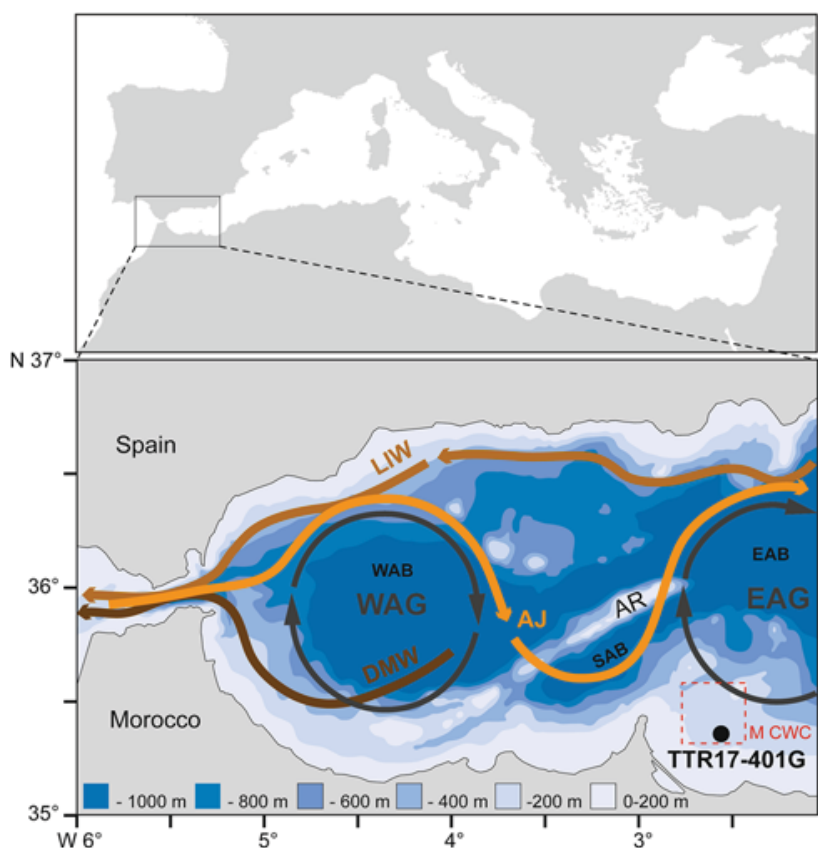

Fig. 1 Bathymetry of the Alboran Sea, simplified large-scale hydrology and location of core TTR17-401G (AJ Atlantic jet, AR Alboran ridge, $D M W$ deep Mediterranean water, $E A B$ eastern Alboran Basin, $E A G$ eastern Alboran/anticyclonic gyre, $L I W$ Levantine intermediate water, $S A B$ southern Alboran Basin, $W A B$ western Alboran Basin, $W A G$ western Alboran/anticyclonic gyre; based on GEBCO: https:// www.gebco.net/data_and_products/gridded_bathymetry_data/; Millot 1987; Viúdez et al. 1998; Comas et al. 1999; Renault et al. 2012; Stalder et al. 2015)

While Fink et al. (2013) identify the Bølling-Allerød interstadial and the Early Holocene as phases of accelerated coral growth linked to increased productivity and mound accumulation in the MMF, Stalder et al. (2015) include the early Younger Dryas based on abundant macroand microfaunal evidence, high flux of labile carbon and sediment inferred accumulation rates.

Since the Palaeozoic ostracods (Crustacea) are a successful and diverse microfossil group that represent excellent palaeoenvironmental indicators characterizing most kinds of aquatic ecosystems (e.g. Smith and Horne 2002, Horne 2003). However, despite about 200 years of research their diversity is not yet fully documented (e.g., Rodriguez-Lazaro and Ruiz-Munoz 2012). In particular, studies on ostracods from cold-water coral ecosystems (CWC) are still scarce (e.g. Coles et al. 1996; Stalder et al. 2014; Sciuto and Rosso 2015), most with only a limited documentation of species based on SEM images. While research history of Recent (e.g. Müller 1894; Bonaduce et al. 1975; Montenegro et al. 1996; Sciuto 2014; Frezza and Di Bella 2015) and Pleistocene (e.g. Ruggieri 1984; Ciampo 2003; Hastrup and Thomsen 2005a, b; Faranda and Gliozzi 2008; Aiello et al. 2015) ostracod assemblages from Mediterranean subbasins is extensive, studies combining benthic Foraminifera and Ostracoda are scarce (Angue Minto'o et al. 2015; Stalder et al. 2015).

So far, only three investigations combining benthic Foraminifera and Ostracoda (and other fossil groups) associated to CWC have been carried out (Coles et al. 1996; Stalder et al. 2014, 2015). Stalder et al. (2015) recently demonstrated that the investigation of both benthic foraminifera and ostracods is giving palaeoecological insights in sediments from CWC ecosystems where the use of geochemical proxies may be limited due to the occurrence of hiatuses, highly fluctuating sedimentation rates and diagenetic overprint.

In the present study we present: (1) The taxonomy and species abundances of ostracods and their palaeoecological context in core TTR401G from the Melilla Mounds Field (Alboran Sea) spanning the last $13.1 \mathrm{ka}$ documented by high resolution scanning electron images and morphological drawings. (2) The morphological variability in valves of Krithe praetexta along the core and its relationship to environmental forcing proposed in Stalder et al. (2015).

\section{Materials and methods}

Ostracoda are derived from the $560 \mathrm{~cm}$ long sediment core TTR17-401G recovered at $251 \mathrm{~m}$ water depth in the eastern Alboran Sea $\left(35^{\circ} 19.273^{\prime} \mathrm{N}, 02^{\circ} 34.001^{\prime} \mathrm{W}\right.$; Fig. 1). Samples were collected directly onboard at intervals of $20 \mathrm{~cm}$. Approximately $10 \mathrm{~g}$ of dry bulk sediments were sieved through three mesh sizes $(63,125$ and $250 \mu \mathrm{m})$ and oven-dried at $40{ }^{\circ} \mathrm{C}$. All ostracods were picked from the residues. Number of individuals is calculated from the sum of carapaces and the highest number of right versus left valves.

The determination of Ostracoda follows the comprehensive overview of Hartmann and Puri (1974). The latter is modified down to superfamily level according to Meisch (2000). The classification of the Trachyleberididae follows Liebau (1975). For a taxonomic remarks, synonymy lists, measurements (including length/height plots) and drawings of muscle scar patterns (Figs. 1-5 suppl.) kindly consult the electronic supplementary material (ESM).

Images of ostracod specimens were taken with a FEI Sirion XL30 FEG scanning electron microscope (SEM) and a Keyence digital light microscope at the University of Fribourg. The specimens were coated with a $40 \mathrm{~nm}$ thick gold layer. The material is stored at the Natural History Museum of Fribourg, Switzerland (ref. numbers NHMF 32931-32980).

The chronology and inferred sediment accumulation rates and hiatuses in the core are based on ${ }^{14} \mathrm{C}$ ages of benthic Foraminifera ("Sediment") and the planktonic 
Foraminifera assemblage shift (for details see Stalder et al. 2015). Discontinuities have been inferred from contradictive ${ }^{14} \mathrm{C}$ ages of $\mathrm{CWC}$ at $12.9,12.6$ and $8.0 \mathrm{ka} \mathrm{BP}$, respectively (Fig. 2). Benthic Foraminifera from core TTR17-401G are recorded and interpreted in detail in Stalder et al. (2015). Based on hierarchical clustering they are grouped in four distinct assemblages.

\section{Results}

Samples from core TTR-401G contain nine species (see Fig. 2 and below), four of which are only represented by adult specimens (for taxonomic remarks, drawings and measurements see supplementary material). The highest species richness of nine taxa and abundance of 18 adult and 27 juvenile specimens is reached at $420 \mathrm{~cm}$ below surface (BSF). Ostracod-barren samples are at 80, 120, 460, 500 and $520 \mathrm{~cm}$ BSF. For Paracypris polita and Cytherella robusta A-1 as well as A-2 stages are documented. Paracypris polita (Fig. 3) is the only consistently occurring and most abundant species in the entire core (Fig. 2).

Based on abrupt diversity and abundance changes the core section is subdivided in three ostracod assemblages:

Ostracod assemblage 1 (OA1) ranges from 560 to $440 \mathrm{~cm}$ below BSF, shows low abundances $(<5$ adult individuals) and contains mainly Paracypris polita, with only two rare accessory taxa (Krithe praetexta, Cytherella robusta).

At $420 \mathrm{~cm}$ BSF diversity and abundance suddenly increase to 9 species and 17 adult respectively 25 juvenile individuals marks the shift to OA2. Species richness (SR) in OA2 fluctuates between 2 and 6 taxa in the interval between 420 and $260 \mathrm{~cm}$ BSF, with adults and juveniles being continuously present. Paracypris polita (Fig. 3), Krithe praetexta (Figs. 6, 7), Cytherella robusta (Fig. 6) and Echinocythereis vidua (Fig. 5) represent the most common taxa. Accessory taxa comprise Macromckenziea ligustica (Fig. 4), Lanceostoma ensiforme (Fig. 4), Bythocythere bradyi (Fig. 5), Cytheropteron cf. hadriaticum (Fig. 4) and a juvenile of Pterygocythereis (Fig. 3), the three latter taxa only occur in OA2. Adults of Krithe praetexta in OA2 are about 7-15\% longer than specimens from OA3 (Figs. 8, 1 suppl.), with a peak size near the middle of the OA2 interval. A similar pattern is displayed by the size distribution of A-1 Krithe instars in OAZ 2.

In the lower part of ostracod assemblage 3 between 240 and $80 \mathrm{~cm}$ BSF the SR never exceeds more than one taxon per sample. Towards the sediment surface from $60 \mathrm{~cm}$ BSF the SR in OA3 steadily increases from 0 to 4 . Altogether OA3 features a slightly higher SR than OA1 (5 vs. 3 taxa), consisting of Paracypris polita, Krithe praetexta and juveniles of Echinocythereis vidua and Cytherella robusta.

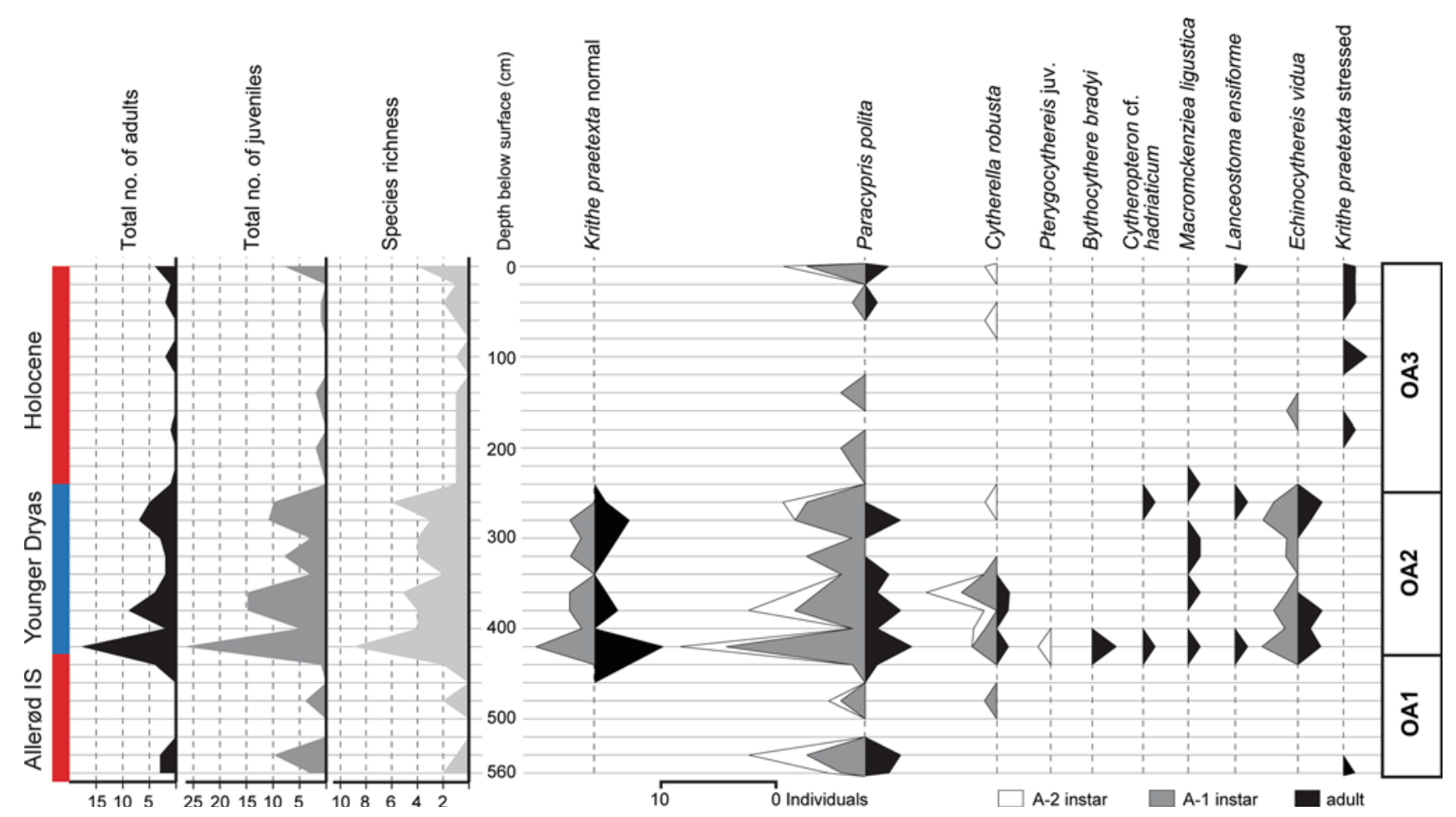

Fig. 2 Diversity, abundance and ostracod assemblages in core TTR17-401G 

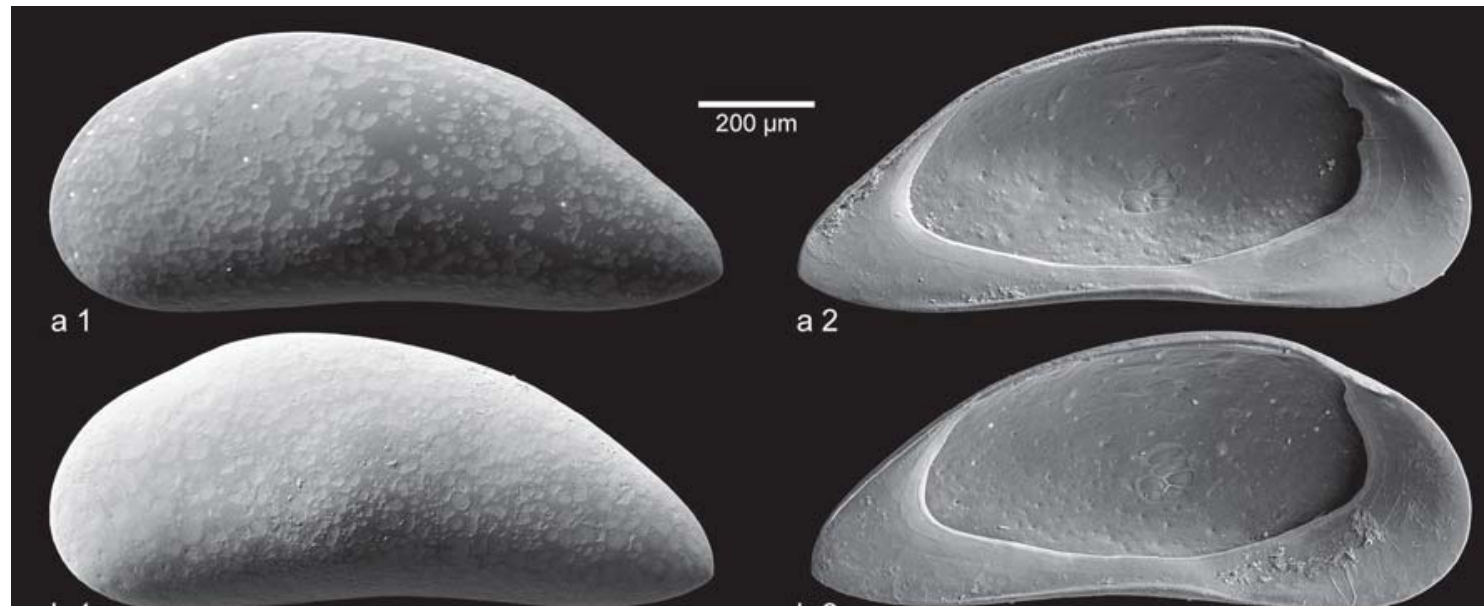

b 1

b 2
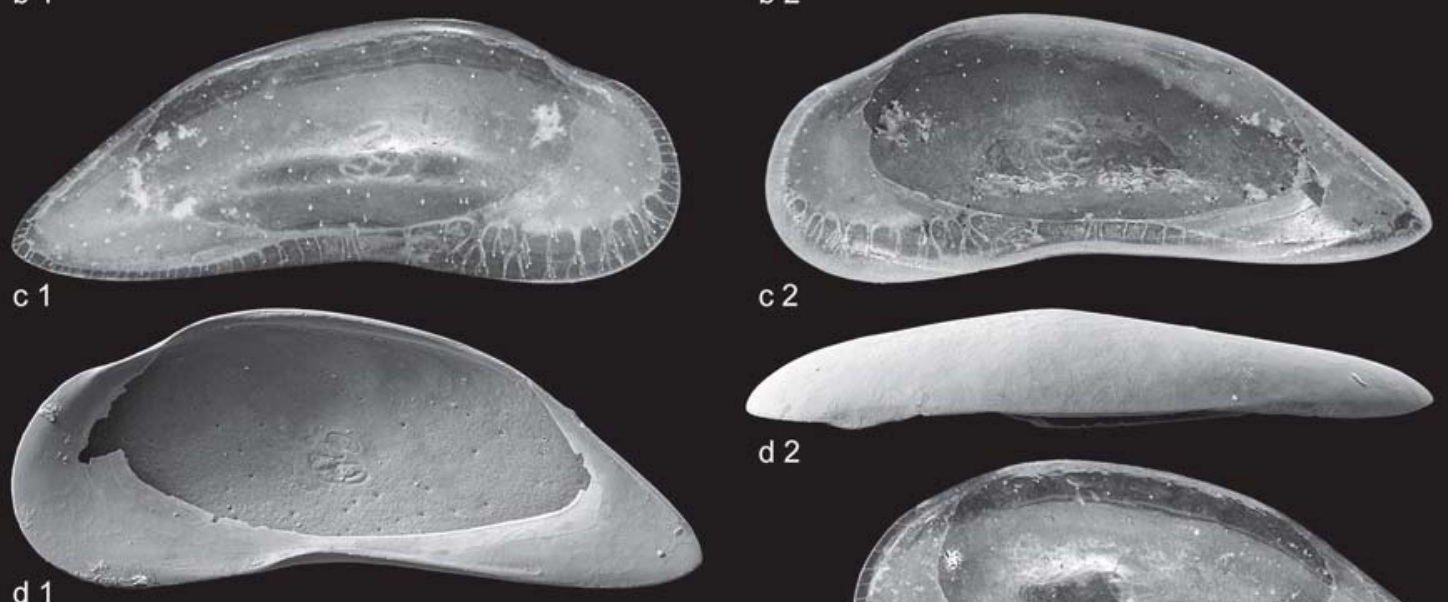

c 2

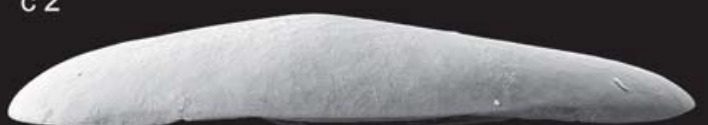

d 2
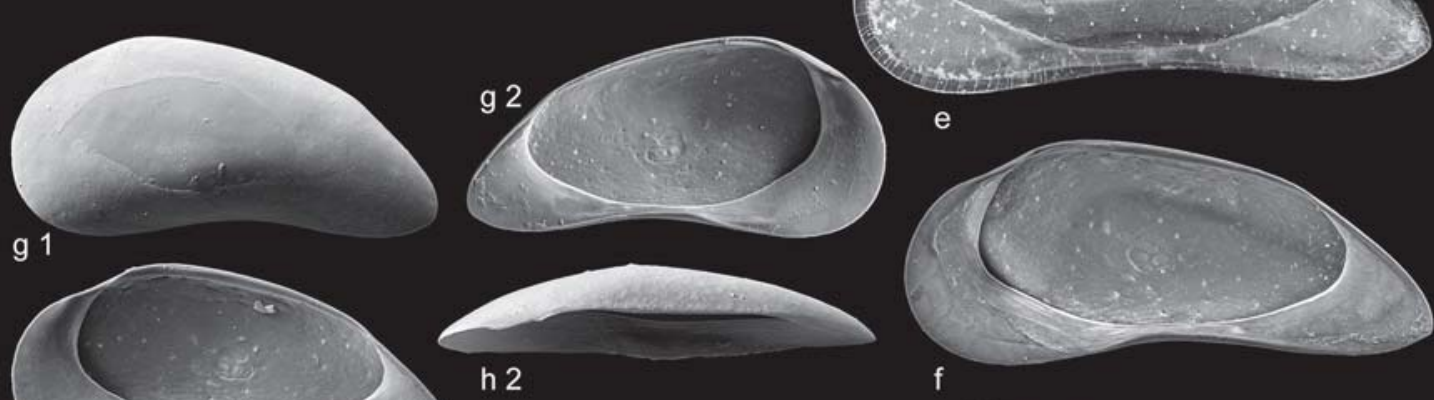

h 1
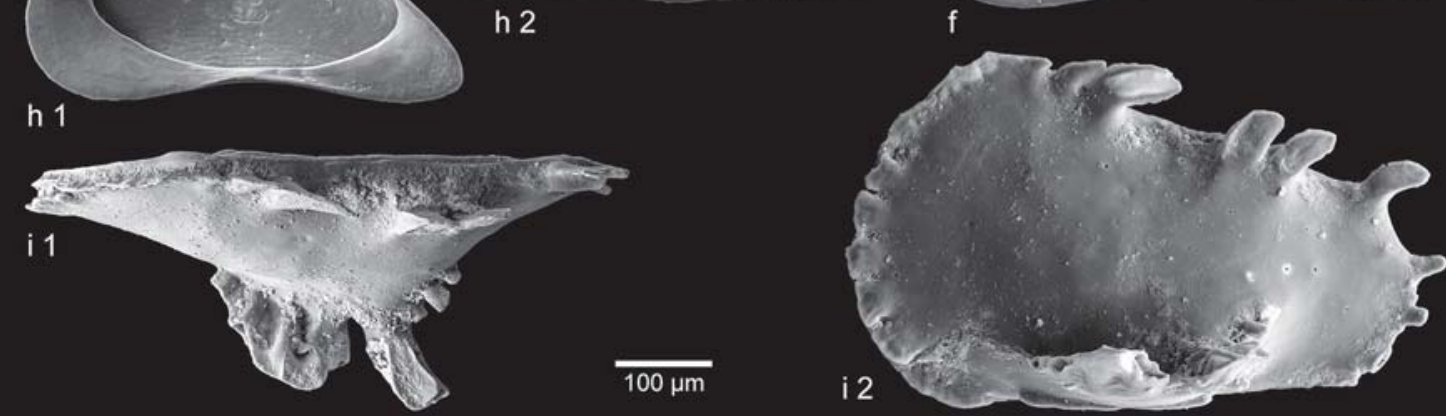

Fig. 3 a Paracypris polita adult left valve $1164 \times 484 \mu \mathrm{m}(280 \mathrm{~cm})$ (MHNF 32947), b Paracypris polita male left valve $1138 \times 478 \mu \mathrm{m}$ $(420 \mathrm{~cm})$ (MHNF 32934), c Paracypris polita male right valve $1154 \times 453 \mu \mathrm{m}(560 \mathrm{~cm})(\mathrm{MHNF} 32980)$, d Paracypris polita female right valve $1193 \times 483 \mu \mathrm{m}(420 \mathrm{~cm})$ (MHNF 32931), e Paracypris polita A-1 instar left valve $996 \times 417 \mu \mathrm{m}(480 \mathrm{~cm})$

(MHNF 32978), f Paracypris polita A-1 instar right valve $941 \times 394 \mu \mathrm{m}(420 \mathrm{~cm})$, g Paracypris polita A-2 instar left valve $731 \times 348 \mu \mathrm{m}(420 \mathrm{~cm})($ MHNF 32945), h Paracypris polita A-2 instar right valve $766 \times 344 \mu \mathrm{m}(420 \mathrm{~cm})($ MHNF 32932), i Pterygocythereis sp. A-3? instar left valve $589 \times 356 \mu \mathrm{m}(420 \mathrm{~cm})$ (MHNF 329357) 


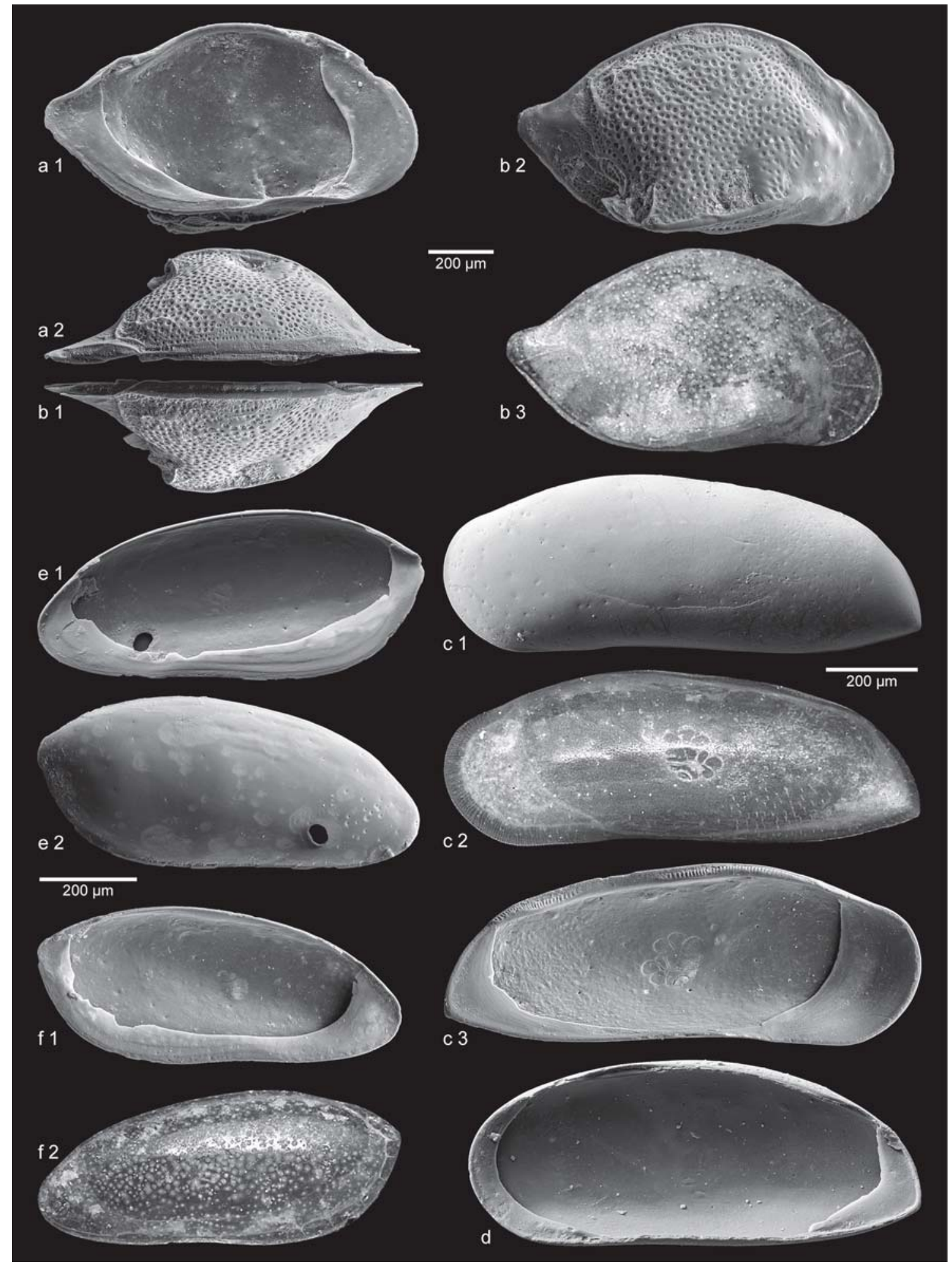

Fig. 4 a Cytheropteron cf. hadriaticum adult left valve $575 \times 297 \mu \mathrm{m}(420 \mathrm{~cm})($ MHNF 32940), b Cytheropteron cf. hadriaticum adult right valve $580 \times 322 \mu \mathrm{m}(260 \mathrm{~cm})$ (MHNF 32951), c Macromckenziea ligustica adult left valve

$1042 \times 394 \mu \mathrm{m}(420 \mathrm{~cm})($ MHNF 32933), d Macromckenziea ligustica adult right valve $989 \times 406 \mu \mathrm{m}(300 \mathrm{~cm})$, e Lanceostoma ensiforme adult right valve $785 \times 355 \mu \mathrm{m}(260 \mathrm{~cm})($ MHNF 32950), f Lanceostoma ensiforme adult left valve $749 \times 324 \mu \mathrm{m}(260 \mathrm{~cm})$ 


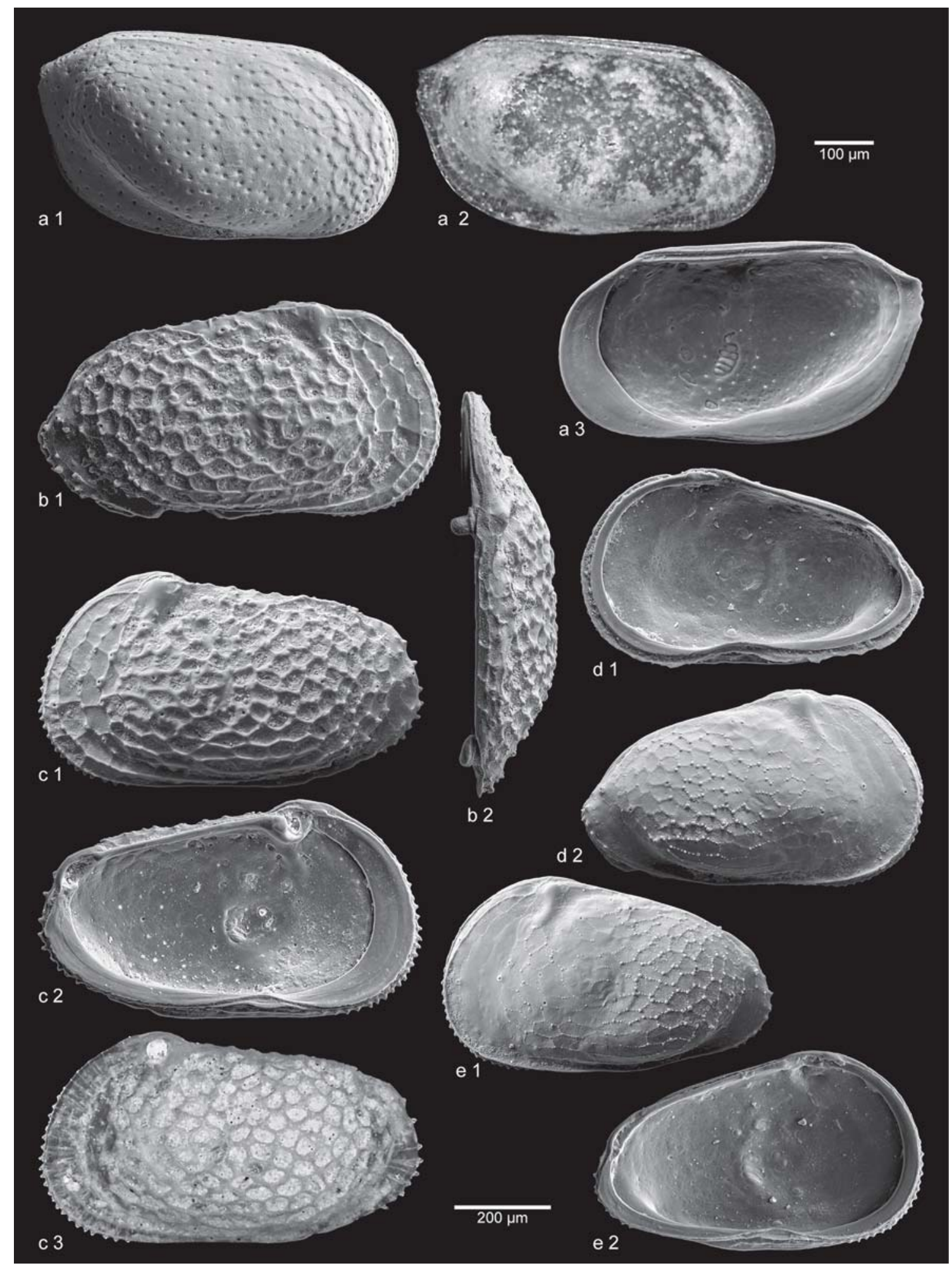

Fig. 5 a Bythocythere bradyi adult right valve $619 \times 341 \mu \mathrm{m}$ $(420 \mathrm{~cm})$ (MHNF 32946), b Echinocythereis vidua adult right valve $831 \times 448 \mu \mathrm{m}(380 \mathrm{~cm})($ MHNF 32952), c Echinocythereis vidua adult left valve $792 \times 464 \mu \mathrm{m} \quad(420 \mathrm{~cm}) \quad($ MHNF 32942$)$, d Echinocythereis vidua A-1 instar right valve $708 \times 408 \mu \mathrm{m}$ $(420 \mathrm{~cm})$ (MHNF 32943), e Echinocythereis vidua A-1 instar left valve $673 \times 413 \mu \mathrm{m}(420 \mathrm{~cm})($ MHNF 32936$)$ 


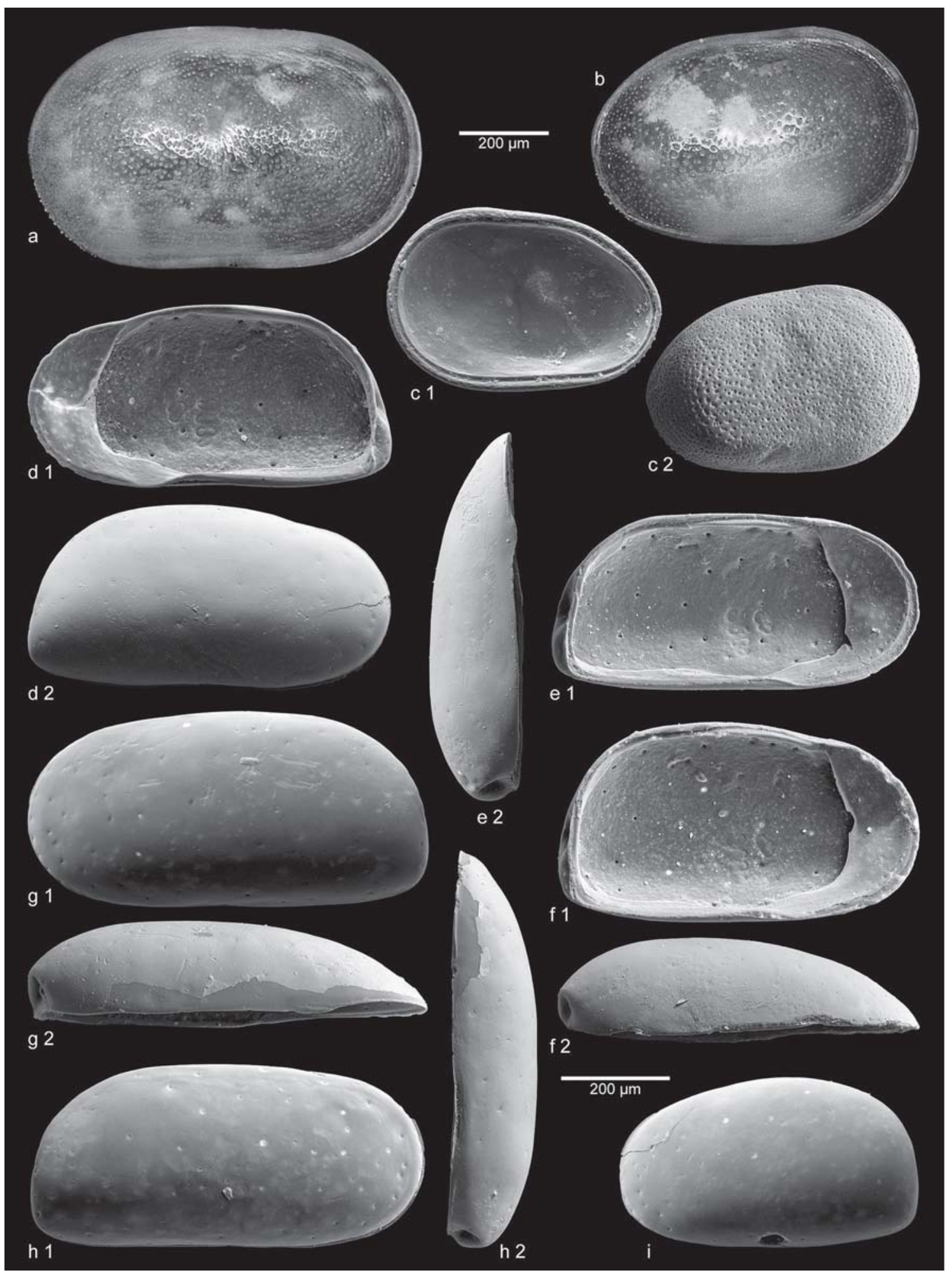

Fig. 6 a Cytherella robusta adult right valve $877 \times 544 \mu \mathrm{m}$ $(420 \mathrm{~cm})$ (MHNF 32975), b Cytherella robusta A-1 instar right valve $732 \times 485 \mu \mathrm{m}(400 \mathrm{~cm})($ MHNF 32974), c Cytherella robusta A-1 instar right valve $615 \times 412 \mu \mathrm{m}(420 \mathrm{~cm})($ MHNF 32941), d Krithe praetexta stressed female right valve $670 \times 336 \mu \mathrm{m}$ $(100 \mathrm{~cm})($ MHNF 32954$)$, e Krithe praetexta stressed male left valve

$679 \times 326 \mu \mathrm{m}(100 \mathrm{~cm})($ MHNF 32953$), \mathbf{f}$ Krithe praetexta stressed female left valve $666 \times 370 \mu \mathrm{m}(100 \mathrm{~cm})(\mathrm{MHNF} 32955)$, g Krithe praetexta male left valve $740 \times 362 \mu \mathrm{m}(280 \mathrm{~cm})($ MHNF 32949), h Krithe praetexta small normal male right valve $726 \times 338 \mu \mathrm{m}$ $(280 \mathrm{~cm})$ i Krithe praetexta A-1 instar left valve $573 \times 326 \mu \mathrm{m}$ $(280 \mathrm{~cm})$ (MHNF 32948) 

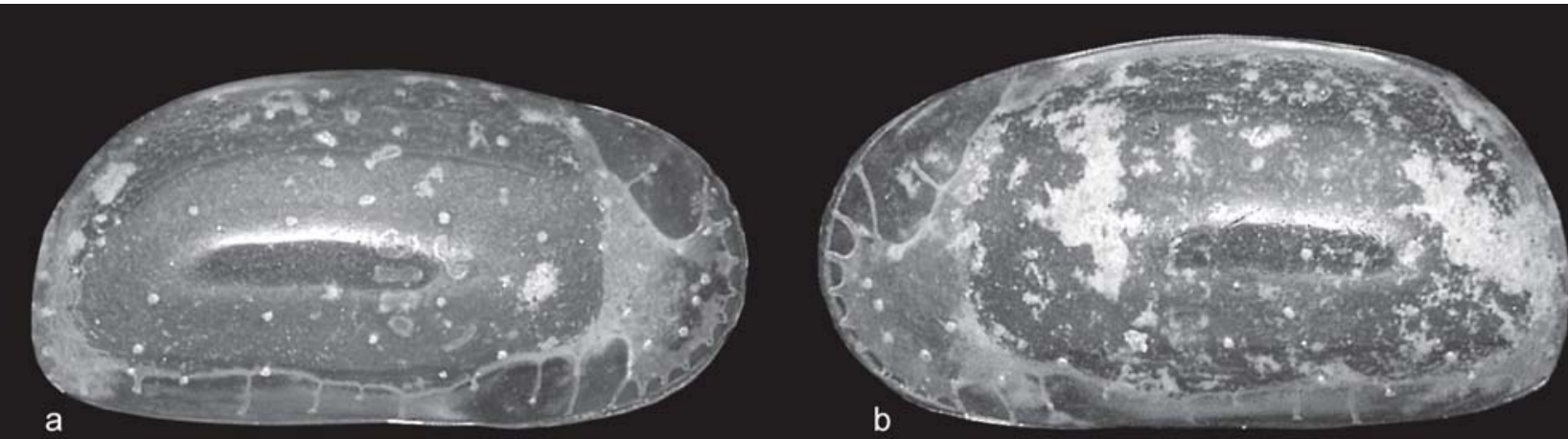

a

b
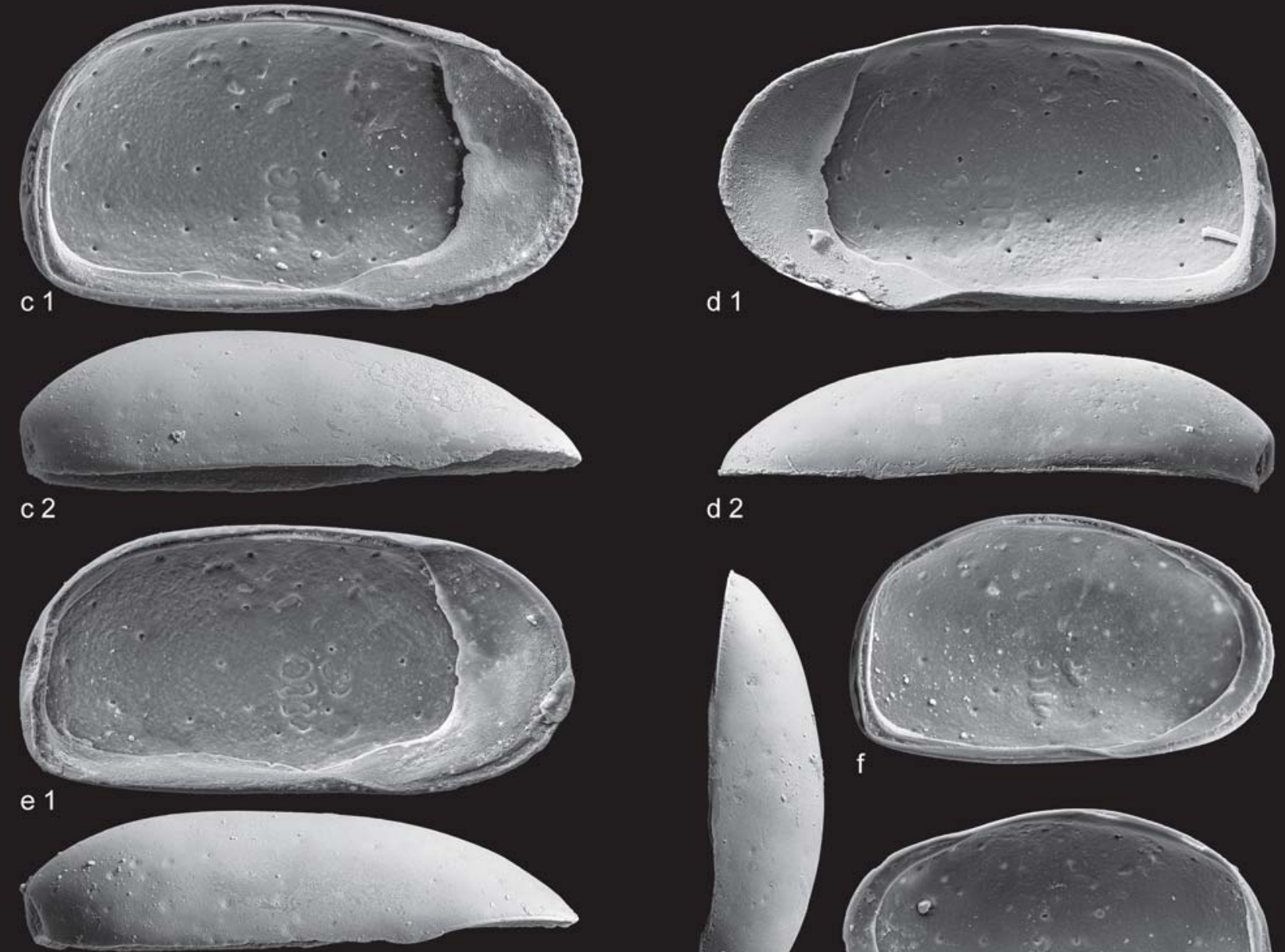

e 2

$200 \mu \mathrm{m}$

g 1

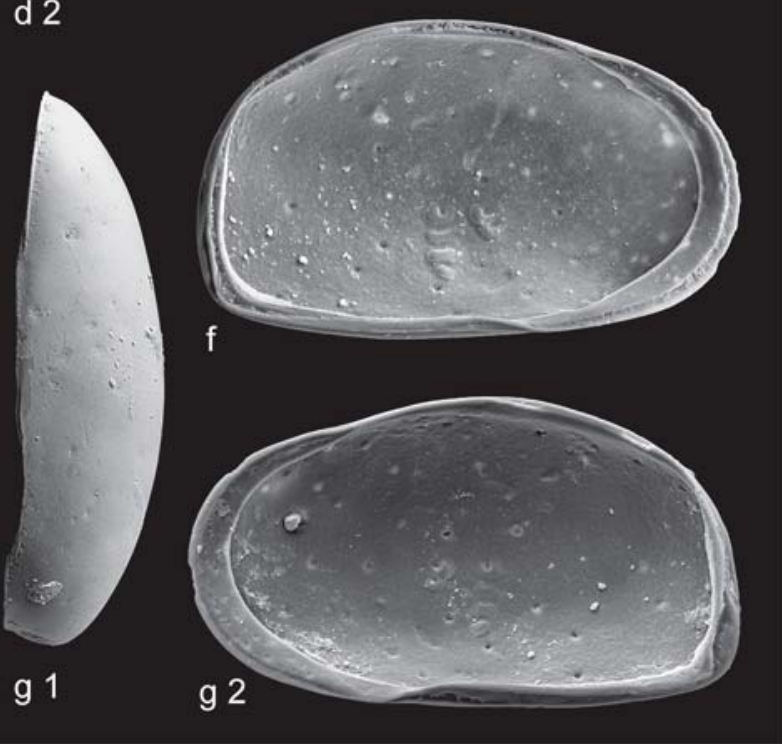

f

Fig. 7 a Krithe praetexta female right valve $754 \times 373 \mu \mathrm{m}(300 \mathrm{~cm})$ (MHNF 32969), b Krithe praetexta very large female left valve $804 \times 419 \mu \mathrm{m}(320 \mathrm{~cm})($ MHNF 32970$)$, c Krithe praetexta female left valve $737 \times 404 \mu \mathrm{m}(420 \mathrm{~cm})($ MHNF 32944), d Krithe prae-

e Krithe praetexta small normal male left valve $726 \times 354 \mu \mathrm{m}$ $(420 \mathrm{~cm})$ (MHNF 32938), f Krithe praetexta A-1 instar left valve $576 \times 340 \mu \mathrm{m}(420 \mathrm{~cm}), \mathrm{g}$ Krithe praetexta A-1 instar right valve $587 \times 332 \mu \mathrm{m}(420 \mathrm{~cm})($ MHNF 32939$)$ 


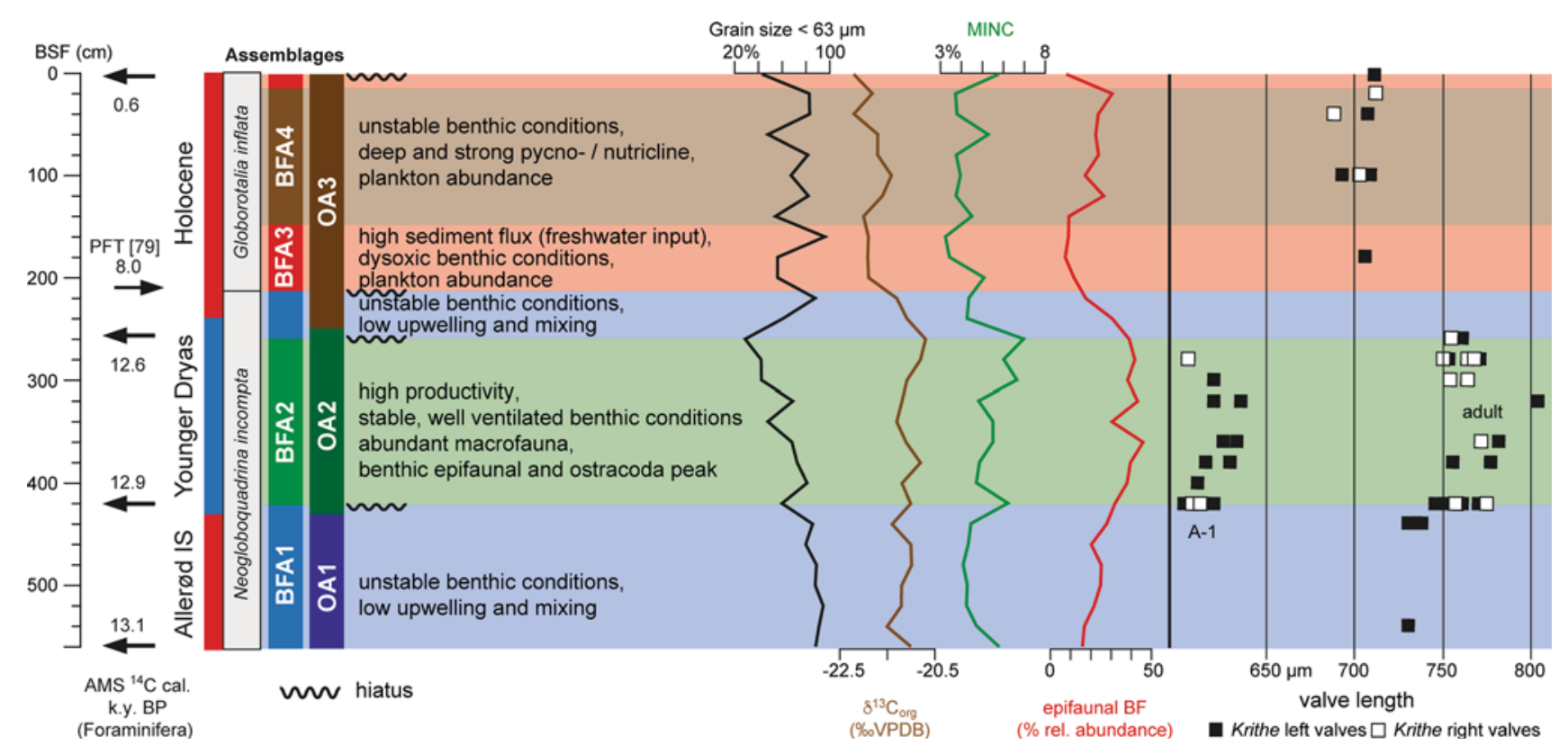

Fig. 8 Temporal and ecological subdivision of core TTR17-401G and corresponding valve length of Krithe praetexta. Benthic (BFA) and planktic Foraminifera assemblages, absolute dating, geochemistry and

grain size according to Stalder et al. (2015) (MINC mineral carbon, $B F$ benthic Foraminifera)

\section{Discussion}

\subsection{Wider palaeoenvironmental context}

There is a general consensus that ostracods do not tolerate truly anoxic conditions, though there are assemblages seemingly adapted to reduced levels of bottom oxygenation (Dingle 1995). This observation coincides with the higher species richness and abundances during BFA2/OA2 (dominance of benthic epifaunal taxa) and OA2, respectively and the inferred increased bottom water ventilation (Stalder et al. 2015; Fig. 8).

Since the genus Krithe has been attributed to the endobenthos (McKenzie et al. 1989; Coles et al. 1994; Majoran and Agrenius 1995), its abundance in BFA2/OA2 also indicates oxygenation of the uppermost sediment layer. This is born out by the more abundant occurrence of larger-sized Krithe praetexta specimens compared to OA1 and $\mathrm{OA} 3$, indicating environmentally stressed specimens not reaching their optimum size (Figs. 8, 5 suppl.). Occurrence peaks of the genus Echinocythereis in so-called "cold-assemblages" has been linked to a mixed water column and abundance of nutrients (Bassetti et al. 2010). Downwelling of more dense surface water in BFA1 and BFA2 probably contributed to the higher levels of bottom water oxygenation and nutrient supply.

Increases of ostracod abundance and species richness as well as an assemblage change comparable to the Melilla CWC mound have been reported in the Younger Dryas of the Mediterranean from non-CWC related settings. Angue

Minto'o et al. (2015) report a shift from a Paracypris polita dominated assemblage during the last glacial period to a diverse assemblage in the Younger Dryas with higher percentages of Krithe spp. and Macrocyprididae comparable to the development in OA2. Absence of ostracods during the Bølling-Allerød interstadial has been linked to increased freshwater influx (Ciampo 2003), as in our samples in OA1.

In a core from the deep southeastern Adriatic Basin (at 1207 mbsl) however, a maximal species richness (17 taxa) was recorded for the Bølling-Allerød interstadial that decreased to 12 and 10 species in the Younger Dryas and earliest Holocene, respectively (Breman 1975). This discrepancy is certainly due to alterations of water circulation patterns (thus benthic conditions) in different Mediterranean subbasins in the last glacial period and the Holocene.

During the younger Dryas peaks of allochthonous Ostracoda have been reported (El Hmaidi et al. 2010; Angue Minto'o et al. 2015) from the Mediterranean. The only species from core $401 \mathrm{G}$ that may be considered as allochthonous is Lanceostoma ensiforme, a species of the predominantly phytal Paradoxostomatidae generally recorded from rather shallow depths (Whatley and Wall 1975; Hull 1999). However, the presence of Paradoxostomatidae in CWCs has been interpreted to represent an in situ depth range extension of shallow-water taxa due to the availability of abundant nutriments (Coles et al. 1996; Sciuto and Rosso 2015). All other ostracod species occur in recent water depth ranges including the water depths 
measured and deduced for core $401 \mathrm{G}$ and are thus considered to represent autochthonous species.

\subsection{Melilla mound context (core TTR-401G)}

Stalder et al. (2015) group the benthic Foraminifera of core TTR-401G in four assemblages (BFA1-4 in Fig. 8). The near absence of ostracods in BFA1/OA2 is due to the instable and insufficiently ventilated bottom water conditions as inferred from the benthic Foraminifera and the geochemical data in Stalder et al. (2015) have been linked to continental and oceanic freshwater inputs, inhibiting the development of a suitable benthic environment favourable for ostracod proliferation.

BFA2 conforms to OA2 and is characterized by high abundances of epifaunal benthic Foraminifera taxa (Cibicides spp., Cibicidoides pachyderma) and a low plankton/ benthos foraminiferal-ratio (P/B-ratio). Discanomalina coronata as taxon representing well-ventilated sea floors (Margreth et al. 2009) is nearly exclusively limited to BFA2/OA2.

Ostracod assemblage 1 and 3 are similar in that they show low diversity (0-2 species per sample) and abundance (adult and juveniles each below 5 specimens per sample), with the main faunal components being Paracypris polita and environmentally stressed (see Sect. 4.1) Krithe praetetxta. While the lower part of BFA1 conforms to OA1, the detailed subdivision of interval $240-0 \mathrm{~cm}$ in a recurring BFA1 and BFA3-4 cannot be reproduced for OA3 (Fig. 8), probably due to the limited sample size and associated few ostracod specimens.

Based on grain size data and lithology provided in Stalder et al. (2015) peaks in ostracod abundance and species richness correlate roughly to a general decrease of the smaller than $63 \mu \mathrm{m}$-fraction in interval $420-260 \mathrm{~cm}$ as well as to maxima in intermediate grain sizes $(63-250 \mu \mathrm{m})$ in samples 380 and $420 \mathrm{~cm}$ (since the $>250 \mu \mathrm{m}$ fraction was not subdivided further it remains difficult to interpret). In general, ostracods are more diverse and abundant on sandy than on clayey mud substrates.

The correlation of ostracod abundance and diversity in relation to sediment grain size has been investigated in the past, however without definite conclusions. Kilenyi (1969) measured grain sizes conducive for high ostracod abundance and diversity in the Thames estuary to generally lie between 100 and $250 \mu \mathrm{m}$. Sediments strongly adverse to ostracod proliferation have been associated with "fluid mud" (thixotrope mud-water mixture) and more than $10 \%$ of the $250-500 \mu \mathrm{m}$ fraction. Since these results were obtained in a high-energy environment unanswered question concerning effects of transport, substrate mobility and sorting remain (e.g. Kilenyi 1969, 1971). Krutak (1971, 1972) reports maximum abundance and diversity from poorly sorted medium and fine sands $(125-500 \mu \mathrm{m})$ of a tidal lagoon in the Gulf of Mexico.

Comparing substrate preferences of recent Mediterranean taxa similar to our species in water depths and lower energy settings comparable to core $401 \mathrm{G}$ (e.g. Adriatic Sea; Bonaduce et al. 1975) is not straightforward, but also seems to indicate a general tendency towards silty and sandy mud.

The interpretation of geochemical proxies sensu Stalder et al. (2015) in relation to the OA subdivision remains more ambiguous, with higher ratios of mineral carbon generally correlating with higher ostracod diversity and abundance. Other geochemical indicators like $\delta^{13} \mathrm{C}_{\text {org }}$ however do not mirror ostracod assemblage development (Fig. 8).

\subsection{Comparison to other CWC mound ostracod assemblages}

The (sub)recent dead and live ostracod taxa recorded from the deeper (505-790 vs. $252 \mathrm{~m}$ ) extant Santa Maria di Leuca CWC mound offshore southern Apulia shows a nearly entirely different species composition (Sciuto and Rosso 2015) compared to uppermost subrecent samples ( $\geq 600$ a BP) in core TTR-401G with two living and 40 subfossil taxa. Accordingly the record features a higher percentage of cold-water and/or deeper-living taxa. On species level only Lanceostoma ensiforme (listed as Paradoxostoma simile in Sciuto and Rosso 2015), Krithe praetexta and Cytheropteron hadriaticum occur in both CWC (with two identical species in the respective surface sample), whereas 7 genera are conform. Interesting is the absence of Paracypris in the Santa Maria di Leuca CWC mound, which is probably due to the greater water depth of the latter.

The much higher overall diversity of 42 versus 4 recent/subfossil ostracod taxa in core TTR-401G may be related to the larger sample volume (300 ccm vs. $10 \mathrm{~g}$ ) or to the larger spectrum of analysed CWC facies (6 vs. 1). Highest diversities in the Santa Maria di Leuca CWC mound are developed in the coral framework (22 species) and Foraminifera marl (25 species) facies, with the latter showing a high percentage of exclusive taxa. The lowest diversity is recorded in the coral rubble facies (4 species). This mirrors the stratigraphical development in core TTR$401 \mathrm{G}$ core, where the occurrence of the benthic foraminifer Discanomalina coronata as indicator for living CWC frameworks (Margreth et al. 2009) is nearly exclusively limited BFA2/OA2, hinting at in situ CWC growth in the lower Younger Dryas, whereas low abundance and diversity in OA1 and OA3 can be attributed to unfavourable bottom conditions and as well as a shift from a coral framework to coral rubble setting. 
Coles et al. (1996) record typical upper bathyal benthic foraminifer and ostracod assemblages from a comparable time-slice (Bølling-Allerød to Recent) of CWC mounds in the Porcupine Basin offshore southwestern Ireland with sample depth ranging from 610 to $750 \mathrm{~m}$. On-mound diversity is much higher than off-mound speculating on the importance of hard substrate for diversity, comparable to the results of the Santa Maria di Leuca CWC mound (see above). Being of deeper northeastern Atlantic provenance, the difference at species level between the Porcupine Seabight and the Melilla Mound Field is not surprising. Only Krithe praetexta is recorded from both sites, whereas Paracypris polita is interpreted as allochthonous. There are 5 conform autochthonous genera.

\section{Conclusions}

The $560 \mathrm{~cm}$ long sediment core TTR17-401G from the Melilla cold-water coral mound field spanning the last $13 \mathrm{ka}$ in the eastern Alboran Sea yielded nine ostracod species, consistently dominated by Paracypris polita. Based on abrupt diversity and abundance changes the core is subdivided in three distinct ostracod assemblages, correlating to the Bølling-Allerød interstadial, the early Younger Dryas and the Holocene, respectively. The highest species richness and abundance is achieved in ostracod assemblage 2 (OA2) that thrived during the early Younger Dryas, indicating prevailing well-oxygenated and nutrientrich bottom conditions. The distribution of distinctly larger specimens of Krithe praetexta in OA2 suggests that ecological conditions were conducive for optimal growth of this species. Environmentally stressed specimens from OA3 and OA1 also show comparatively shorter lateral outlines. Higher ostracod abundances and species richness generally correlate with a decrease of the silt/clay- and an increase of fine-medium sand-fraction. These results corroborate the interpretation of geochemical and faunal proxies of core TTR17-401G elaborated in a previous study.

The taxonomical analysis of the ostracod taxa reveals well know and expected species from the geographical position and the intermediate water depth, with the exception of Bythocythere bradyi being for the first time recorded in the Mediterranean. The higher ostracod abundance and species richness in OA2 in the early Younger Dryas and the subsequent depletion in OA3 during the Holocene mirrors ostracod assemblage shifts reported elsewhere in the Mediterranean.

Acknowledgements We thank the captain and crew of research vessel "Professor Logatchev" for their valuable help onboard. Two anonymous reviewers are acknowledged for their detailed comments and valuable suggestions.

\section{References}

Aiello, G., Barra, D., \& Parisi, R. (2015). Lower-Middle Pleistocene ostracod assemblages from the Montalbano Jonico section (Basilicata, Southern Italy). Quaternary International, 383, 47-73.

Angue Minto'o, C. M., Bassetti, M. A., Morigi, C., Ducassou, E., Toucanne, S., Jouet, G., et al. (2015). Levantine intermediate water hydrodynamic and bottom water ventilation in the northern Tyrrhenian Sea over the past 56,000 years: New insights from benthic foraminifera and ostracods. Quaternary International, 357, 295-313.

Bassetti, M. A., Carbonel, P., Sierro, F. J., Perez-Folgado, M., Jouët, G., \& Berné, S. (2010). Response of ostracods to abrupt climate changes in the Western Mediterranean (Gulf of Lions) during the last 30 kyr. Marine Micropaleontology, 77, 1-14.

Bonaduce, G., Ciampo, G., \& Masoli, M. (1975). Distribution of Ostracoda in the Adriatic Sea. Pubblicazioni della Stazione zoologica di Napoli, 40(suppl.), 1-304.

Breman, E. (1975). Ostracodes in a bottom core from the deep southeastern basin of the Adriatic Sea. Proceedings of the Koninklijke Nederlandse Akademie van Wetenschappen, series B, 78(3), 197-218.

Ciampo, G. (2003). Reconstruction of Late Pleistocene-Holocene palaeobathymetries from Ostracoda on the Tyrrhenian continental shelf. Géobios, 36, 1-11.

Coles, G. P., Ainsworth, N. R., Whatley, R. C., \& Jones, R. W. (1996). Foraminifera and ostracoda from Quaternary carbonate mounds associated with gas seepage in the Porcupine Basin, offshore western Ireland. Revista Española de Micropaleontología, 28(2), 113-151.

Coles, G. P., Whatley, R. C., \& Moguilevsky, A. (1994). The ostracod genus Krithe from the Tertiary and Quaternary of the north Atlantic. Palaeontology, 37(1), 71-120.

Comas, M. C., Platt, J. P., Soto, J. I., \& Watts, A. B. (1999). The origin and tectonic history of the Alboran Basin; insights from LEG 161 results. Proceedings of the Ocean Drilling Program. Scientific Results, 161, 555-580.

Dingle, R. V. (1995). Continental shelf upwelling and benthic Ostracoda in the Benguela System (southeastern Atlantic Ocean). Marine Geology, 122, 207-225.

El Hmaidi, A., El Moumni, B., Nachite, D., Bekkali, R., \& Gensous, B. (2010). Distribution et caractéristiques des associations d'ostracodes au Pléistocène supérieur et Holocène au niveau de la marge orientale du détroit de Gibraltar (mer d'Alboran, Maroc). Revue de Micropaléontologie, 53, 17-28.

Faranda, C., \& Gliozzi, E. (2008). The ostracod fauna of the PlioPleistocene Monte Mario succession (Roma, Italy). Bolletino della Società Paleontologica Italiana, 47(3), 215-267.

Fink, H. G., Wienberg, C., De Pol-Holz, R., Wintersteller, P., \& Hebbeln, D. (2013). Cold-water coral growth in the Alboran Sea related to high productivity during the Late Pleistocene and Holocene. Marine Geology, 339, 71-82.

Frezza, V., \& Di Bella, L. (2015). Distribution of recent ostracods near the Ombrone River mouth (Northern Tyrrhenian Sea, Italy). Micropaleontology, 61(1-2), 101-114.

Hartmann, G., \& Puri, H. S. (1974). Summary of neontological and paleontological classification of Ostracoda. Mitteilungen des Hamburgischen Zoologischen Museum und Institut, 70, 7-73. 
Hastrup, A., \& Thomsen, E. (2005a). Paleoenvironmental interpretation of the Plio-Pleistocene Kallithea Bay section, Rhodes, Greece. Cushman Foundation Special Publication, 39, 159-191.

Hastrup, A., \& Thomsen, E. (2005b). Systematic paleontology and ecology of ostracods from the Plio-Pleistocene Kallithea Bay section, Rhodes, Greece. Cushman Foundation Special Publication, 39, 193-279.

Horne, D. J. (2003). Key events in the radiation of the Ostracoda. In L. E. Park, \& A. J. Smith (Eds.), Bridging the gap: trends in the ostracode biological and geological sciences. The Palaeontological Society Papers (Vol. 9, pp. 181-201), New Haven, CT: The Paleontological Society.

Hull, S. L. (1999). Comparison of tidepool phytal ostracod abundance and assemblage structure on three spatial scales. Marine Ecology Progress Series, 182, 201-208.

IHO (International Hydrographic Organization) (1953). Limits of oceans and seas (3rd ed.). Monte-Carlo: Imprimerie Monégasque, Special publication No 28.

Kilenyi, T. I. (1969). The problems of ostracod ecology in the Thames Estuary. In J. W. Neale (Ed.), The taxonomy, morphology and ecology of recent Ostracoda (pp. 251-267). Edinburgh: Oliver \& Boyd.

Kilenyi, T. I. (1971). Some basic questions in the palaeoecology of ostracods. Bulletin du Centre de Recherche de Pau-SNPA, 5(suppl.), 523-543.

Krutak, P. R. (1971). The recent Ostracoda of Laguna Mandinga, Veracruz, Mexico. Micropaleontology, 17(1), 1-30.

Krutak, P. R. (1972). Some relationship between grain size of substrate and carapace size in modern brackish-water Ostracoda. Micropaleontology, 18(2), 153-159.

Liebau, A. (1975). Comment on suprageneric taxa of the Trachyleberididae s.n. Neues Jahrbuch für Geologie und Paläontologie, Abhandlungen, 148(3), 353-379.

Majoran, S., \& Agrenius, S. (1995). Preliminary observations on living Krithe praetexta praetexta (Sars, 1866), Sarsicytheridea brudii (Norman, 1865) and other marine ostracods in aquaria. Journal of Micropalaeontology, 14, 96.

Margreth, S., Rüggeberg, A., \& Spezzaferri, S. (2009). Benthic foraminifera as proxies for cold-water coral reef ecosystems along the Irish Margin. Deep-Sea Research Part I, 56, 2216-2234.

McKenzie, K. G., Majoran, S., Emami, V., \& Reyment, R. A. (1989). The Krithe problem-first test of Peypouquet's hypothesis, with a redescription of Krithe praetexta praetexta (Crustacea, Ostracoda). Palaeogeography, Palaeoclimatology, Palaeoecology, 74, 343-354.

Meisch, C. (2000). Freshwater Ostracoda of western and central Europe (Süßwasserfauna von Mitteleuropa Band 8 Crustacea, Heft 3 Ostracoda). Heidelberg, Berlin: Spektrum Akademischer Verlag.

Millot, C. (1987). Circulation in the western Mediterranean Sea. Oceanologica Acta, 10(2), 143-149.

Montenegro, M. E., Pugliese, N., \& Bonaduce, G. (1996). Shelf ostracods distribution in the Italian seas. In S. Crasquin-Soleau,
E. Braccini, \& F. Lethiers (Eds.), What about Ostracoda? Bulletin des Centre de Recherches Elf Exploration Production, Mémoirs (Vol. 20, pp. 91-101), 3rd European Ostracodologists Meeting, Paris - Bierville, France, 8-12 July 1996, Pau CEDEX.

Müller, G. W. (1894). Fauna und Flora des Golfes von Neapel und der angrenzenden Meeres-Abschnitte, 21. Monographie: Ostracoden. Berlin: Friedländer and Sohn.

Prieur, L., \& Sournia, A. (1994). “Almofront-1" (April-May 1991): An interdisciplinary study of the Almeria-Oran geostrophic front, SW Mediterranean Sea. Journal of Marine Systems, 5, 187-203.

Renault, L., Oguz, T., Pascual, A., Vizoso, G., \& Tintore, J. (2012). Surface circulation in the Alborán Sea (western Mediterranean) inferred from remotely sensed data. Journal of Geophysical Research, 117, C08009.

Rodriguez-Lazaro, J., \& Ruiz-Munoz, F. (2012). A general introduction to Ostracods: Morphology, distribution, fossil record and applications. Developments in Quaternary Science, 17, 1-14.

Ruggieri, G. (1984). Gli ostracodi del Pleistocene inferior di Rizzolo studiati da Seguenza. Naturalista Siciliano, 8(3-4), 121-131. (series 4).

Sciuto, F. (2014). Initial report on ostracod fauna from the Messina Straits (Ionian Sea, northeastern Sicily). Bolletino della Società Paleontologica Italiana, 53(2), 121-134.

Sciuto, F., \& Rosso, R. (2015). Bathyal ostracods from the Santa Maria di Leuca deep-water coral province (northern Ionian Sea). Palaeontologia Electronica, 18.2.22A, 1-17.

Smith, A. J., \& Horne, D. J. (2002). Ecology of marine, marginal marine and non-marine ostracodes. In J. A. Holmes \& A. R. Chivas (Eds.), The Ostracoda: Applications in Quaternary research. AGU Geophysical Monograph (Vol. 131, pp. 37-64). American Geophysical Union.

Stalder, C., Spezzaferri, S., Rüggeberg, A., Pirkenseer, C., \& Gennari, G. (2014). Late Weichselian deglaciation and early Holocene development of a cold-water coral reef along the Lopphavet shelf (Northern Norway) recorded by benthic foraminifera and ostracoda. Deep-Sea Research II, 99, 249-269.

Stalder, C., Vertino, A., Rosso, A., Rüggeberg, A., Pirkenseer, C., Spangenberg, J. E., et al. (2015). Microfossils, a key to unravel cold-water carbonate mound evolution through time: Evidence from the eastern Alboran Sea. PLoS One, 10(10), e0140223.

Vargas-Yáñez, M., Plaza, F., García-Lafuente, J., Sarhan, T., Vargas, J. M., \& Vélez-Belchi, P. (2002). About the seasonal variability of the Alboran Sea circulation. Journal of Marine Systems, 35, 229-248.

Viúdez, A., Pinot, J.-M., \& Haney, R. L. (1998). On the upper layer circulation in the Alboran Sea. Journal of Geophysical Research, 103(C10), 21653-21666.

Whatley, R. C., \& Wall, D. R. (1975). The relationship between Ostracoda and algae in littoral and sublittoral marine environments. Bulletins of American Paleontology, 65(282), 172-202. 